\title{
Greening of agricultural production is the main vector of development of the Russian agricultural sector
}

\author{
Tatiana E. Marinchenko* \\ Rosinformagrotekh, Moscow region, Russia
}

\begin{abstract}
The introduction of biological agents to protect and control, as well as stimulate the development of agricultural crops, is one of the areas of increasing the efficiency and profitability of production, reducing the environmental burden and increasing the competitiveness of producers, which lies in the concept of a green economy, as well as for the sustainable development of agriculture. Domestic biotechnological developments for crop production are considered, which increase production efficiency and reduce the environmental burden.
\end{abstract}

\section{Introduction}

"Green economy" is a new understanding of economic growth that offers to take into account environmental damage and other losses of national wealth related to the economic growth caused to the environment.

According to the most complete, in the opinion of many experts, definition given by experts of the United Nations Environment Program (UNEP) in 2011, the "green economy" is "an economic model that leads to improved human well-being and social equality, reducing environmental risks and deficits” [1]. In essence, such an economy is low-carbon, energy and resource efficient, and includes the solution of social problems.

Ever increasing demand for food to feed the ever-growing population led to development and adoption of synthetic chemicals as a quick and effective strategy of managing crop pests and diseases. However, overreliance on synthetic pesticides is discouraged due to their detrimental effects on human health, the environment, and development of resistant pest and pathogen strains. This, coupled with increasing demand for organically produced foods, stimulated search for alternative approaches and botanical pesticides are particularly gaining importance [2].

Therefore, they can be incorporated into integrated pest management systems and contribute to sustainable agricultural production.

Previous and existing agricultural practices have contributed to environmental pollution, which negatively affects food security, human health and climate. However, agriculture is central link to addressing FAO's social goals for sustainable development. [3]. Therefore, there is a need to move from "non-biological” practices to more environmental practices.

\footnotetext{
* Corresponding author: 9419428@mail.ru
} 
Differences in pollution levels in different countries require regional changes or intervention in agri-food practices to reduce global pollution.

There is worldwide concern about the environmental costs of conventional intensification of agriculture. Growing evidence suggests that ecological intensification of mainstream farming can safeguard food production, with accompanying environmental benefits.

Ecological intensification has been proposed as a nature-based alternative that complements or (partially) replaces non-biological agents, such as agro-chemicals to sustain agricultural production while minimizing adverse effects on the environment.

Governments from multiple countries are starting to consider ecological intensification as an environmentally friendly way towards food security by supporting this process. In some regions, notably Europe and North America, this was due to significant government spending to partially compensate farmers for the costs of greening [4].

\section{Results}

As part of the greening production strategy, many manufacturers are beginning to reduce the use of fertilizers, crop protection agents, regulators and growth promoters of non-biological origin.

The main incentives for the use of biological products in the agricultural sector are: reducing the environmental load on the environment and cultivated objects; restoring the natural potential of production factors; improving product quality and obtaining organic products [5].

The market of biological agents for stimulating and protecting plants in Russia is actively developing, intensive research is being carried out, including that at the All-Russian Research Institute for Biological Protection of Plants, new products are being introduced to the market, some of which are unique.

In recent years, the "State catalog of pesticides and agrochemicals approved for use on the territory of the Russian Federation” includes a number of new biological products for protecting crops from diseases of various etiologies (Alirin-B, Gamair, Vitaplan, Trichocin, Sternifag, Gliokladin) developed by specialists of the All-Russian Research Institute of Plant Protection and Agrobiotechnology LLC.

One of the innovative developments of young scientists is the unique fertilizer based on the BIO-SILICIUM biologically active silicon made by AT CHROM TRADING LLC, which allows increasing crop yields, restoring depleted soil, while improving product quality.

Fertilizer users noted that the BIO-SILICIUM group of agents have no analogues in the world in quality, effectiveness and composition, in which pure mineral silicon (46.3\%) is in a free and biologically active easily digestible form due to the use of nanotechnology. The complex also includes the elements necessary for plants in an accessible form: iron, copper, zinc.

The effectiveness is confirmed by the numerous test results of the agent in various regions on a variety of cultures. In 2017, in the Altai Territory based on the Karavaev FE farm facilities, tests on spring wheat of the Altai variety with the $\mathrm{BioSi}+$ agent ensured an increase in the yield of 3.4 hundredweight / ha (21.3\%) in relation to the control, and when processing Corypheus oats with this agent, the excess in relation to the control in terms of the estimated yield due to the use of the BioSi agent amounted to 10.3 hundredweight / ha (23.3 \%). Avangard LLC, Ryazan Region, performed tests on Gala potatoes: an experimental plot featured a yield of $420 \mathrm{~kg} / \mathrm{ha}$ (+ $10 \mathrm{~kg}$ ), and the control plot featured a yield of $410 \mathrm{~kg} / \mathrm{ha}$. Winter wheat of the Scepter cultivar was processed at Makeevo CJSC (Moscow Region) with a yield increase of $27.7 \%$. In the Republic of Tatarstan, the agent was tested based on AGROSILA JSC and AF Kama LLC, where the increase in yield after processing spring rape of Ratnik varieties was $23.5 \%$. 
This is not a complete list of crops that have improved as a result of the use of biologically active silicon.

BIO-SILICIUM is used on grain crops for pre-sowing seed treatment and spraying of vegetative plants. Pre-sowing treatment allows obtaining friendly strong seedlings with a well-developed root system and a powerful tillering node, strengthens the protective functions of plants in the initial period of growth. The introduction of the agent in the tillering phase or at the beginning of the stem elongation increases stress tolerance, activates the vital processes of plants, stimulates the growth of photosynthetically active leaf surface, increases the number of productive ears and the mass of grains, and strengthens the stems. The powerful development of the root system contributes to the survival of winter crops in severe frosts, especially in the absence of snow cover. When using the agent, the infectivity of barley crops with solid smut and helminthosporiosis decreases; the agent profit is also a significant and stable increase in gluten content [6].

Considerable evidences on the role of plant beneficial microbes on altering the morphology of plant, manage pests and enhancing growth and immunity of plants and positive impact on mineral acquisitions are available. Different plant beneficial microorganisms, solubilize mineral and nutrients in the soil, mitigate resistance to environmental stresses, suppress pathogens, improve plant growth and yield, therefore can be a potential alternate to increase agricultural productivity.

The beneficial microorganisms and their products are extensively explored to facilitate their use for a sustainable and enhanced crop productivity [7].

For example, rhizospheric microorganisms are able to colonize rhizosphere and to improve plant growth, development and nutrient use efficiency by means of a wide variety of mechanisms like organic matter mineralization, biological control against soil-borne pathogens, biological nitrogen fixation, potassium, phosphorous and zinc solubilization and root growth promotion. The modern plant growing depends on chemical fertilizer input, which results in overuse of fertilizers but ignores the biological potential of roots or rhizosphere for efficient mobilization and acquisition of soil nutrients. A very interesting feature of rhizospheric microorganisms is their ability of enhancing nutrient bioavailability 20 to $40 \%$. [8].

Khimsnab Company proposed a new biological product called Rhizoverm developed by scientists of the Vyatka State Agricultural Academy and St. Petersburg State Agrarian University. The agent successfully passed production tests at the farms of the Kirov Region, the republics of Mari El, Tatarstan, and the Udmurt Republic. It was found that by increasing the total amount of root weight and nodules, it contributes to the enrichment of the soil with a significant amount of organic matter with a high nitrogen content, as a result of which the yield of subsequent crops increases by an average of 1 to 2 hundredweight / ha.

With the introduction of new cultures (goat shed, alfalfa, lupine), the efficiency of bacterization can reach 50 to $100 \%$. On average, the agronomic efficiency of Rhizoverm for legumes is 20 to $60 \%$.

Legumes are a source of protein; they are also in high demand in the field of food and feed production. Rhizoverm contains highly effective strains of nodule bacteria that enter into symbiosis with the root system of legumes, increases the productivity of legumes by 20 to $60 \%$ (Eastern goatskin by 100\%), enhances their stress resistance, and improves soil fertility. Rhizoverm does not require special precautions and does not have a phytotoxic effect on cultivated plants, i.e. it is safe for people, animals and plants. The cost of the agent is 1.5 times lower than the cost of other agents based on nodule bacteria [9].

The Bionovatik Company has developed an innovative plant growth regulator called Biodux based on natural components: biologically active polyunsaturated fatty acids (arachidonic, eicosapentaenoic, etc.) of the Mortierella alpina lower soil fungus. In extremely small amounts, these acids provide long-term systemic resistance of plants, which 
is formed by simulating the early stages of their infection with phytopathogens, which enhances the activity of genes responsible for immunity, while their own growth factors are synthesized.

Biodux activates growth and biological processes, forms non-specific systemic resistance (to fungi, bacteria, viruses) in plants for one to two months. The agent is not phytotoxic, does not pollute ground and surface water, does not accumulate in soils, and most importantly, it is safe for humans, fish, beneficial insects, including bees. There are no restrictions on crop variation in crop rotation.

Positive results were obtained when applying Biodux on wheat, barley, rye, soy, sugar and table beets, sunflowers, carrots, corn, potatoes, buckwheat, peas, tomatoes, cucumbers, cabbage, onions, grapes and other plants.

Using Biodux is economically profitable: the number of early products increases, the fruiting period increases, yield increases up to 20 to $30 \%$, the resistance of plants to late blight, alternariosis, rhizoctoniasis, blackleg, real and downy mildew, gray and white rot, bacteriosis, and various species scab and other diseases increases [10].

The AGAT-25K (Khimsnab LLC) agent is a biological product of complex action. It induces the protective properties of plants against pathogens of fungal and bacterial diseases, powdery mildew, late blight, rhizoctonia, improves the mineral nutrition of plants, increases the germination and energy of seed germination, stimulates growth and development. The AGAT-25K successfully passed tests on spring wheat. According to the observations of specialists of the All-Russian Research Institute of Phytopathology of the Russian Academy of Sciences, in addition to the direct effect on the listed diseases, the agent is able to reduce the incidence of plants due to its pronounced growth-promoting properties.

Studies on other crops showed that when using the AGAT-25K agent in pre-sowing seed treatment, an increase in field germination of wheat / barley by $5 \% / 30 \%$ respectively is noted; the planting density increases by 8 and $14 \%$ respectively; growth of the stem and roots is enhanced; wintering of crops is improved; the septoria infection is reduced by $40 \%$; the development of root rot of wheat / barley decreases by $56 \%$ / $64 \%$ respectively. In field trials, the biological effectiveness of the AGAT-25K agent against dusty smut of spring barley was $81.7 \%$ and $73 \%$ against hard smut.

The treatment of seeds with the agent provides an average of an additional $4 \mathrm{~kg} /$ ha of winter wheat, spring barley, sunflower and peas, while protecting plants from root rot, soil and aerogenic infections. The AGAT-25K agent is used in conjunction with insecticides to increase the yield of grain, potatoes, vegetables by an average of $40 \%$, in contrast to the use of pure insecticides, as well as it is used along with mineral fertilizers to reduce their consumption by an average of $30 \%$ [11].

Russian experts brought to the market preparations that provide new opportunities for providing plants with the necessary substances. These include preparations of the Kora line produced by the Azur-Niva Integrated Plant for Agricultural Technologies.

It is proved that plants feed through the leaf apparatus in the same way as through the root system, and in some phases of growth, they feed mainly through the leaf apparatus. Russian scientists have created unique polymer matrices capable of retaining nitrogen, phosphorus and potassium ions in their cells both in mono-element form, and in various proportions. Today, formulations containing N, P, PK and NPK are registered and approved for use. Applied in typical for farmer amounts of 0.5-1.0 L / ha, these fertilizers provide plants with a significant part of the nutrients and compensate for the removal of the main nutrition from the soil.

In addition to the fact that the polymer matrix itself is enriched with macroelements, it is capable of emitting ions of nutrients, which it is adjusted for, from the environment, and transporting them to the plant. The polymer itself remains on the leaf apparatus for up to three weeks. 
According to the results of the experiment with the Kora $\mathrm{R}$ agent on winter wheat of the Governor of the Don variety planted in the tillering phase, the yield increase was 11.5 hundredweight / ha, and 57.8 hundredweight / ha in the control field.

The agent has proved to be excellent in sunflower; the use of Kora R or Kora RK agents on this crop is recommended in the phase of 2 to 4 leaf pairs, and the Kora R or Kora NRK2 is recommended to be used in the phase of 7-9 pairs of leaves depending on the state of the crop. The Kora NRK2 agent is recommended to be used on corn [12].

Specialists' interest was aroused by a new plant growth regulator with a fungicidal and bactericidal effect based on the stabilized colloidal silver called Zerebra Agro (AgroKhimProm and MV Lomonosov Moscow State University). The agent effects are increased germination energy and increased seed germination, evenness of seedlings, activation of the development of a powerful root system, effective inhibition of the development of fungi and bacteria, strengthening the immune system of plants and reducing stress, improving product quality, and increasing yield. The agent was evaluated by agronomists of large holdings and small farms. It has been used since 2014 in Russia and several countries of the world $[13,14]$.

\section{Discussion}

Given the growing global food demands and the hazards associated with the overuse of chemical fertilizers and pesticides, biological plant protection and stimulation are a promising and environmentally friendly alternative to agrochemicals [15].

The concepts of a green economy and sustainable agriculture propose the crop management methods that address the interdependent goals of increasing or at least maintaining crop yields while protecting the environment, conserving natural resources and slowing climate change.

Investments in agricultural innovation by both the public and private sector in the basics of agronomy, plant breeding, biotechnology, and engineering have demonstrated the ability to deliver on the four objectives of agricultural sustainability [16].

In accordance with the "Strategy for the Ecological Safety of the Russian Federation for the period until 2025”, environmental safety must be ensured, among others, through the introduction of innovative and environmentally friendly technologies and development of environmentally friendly industries.

Therefore, many agricultural producers are implementing measures to greening production, which involves the gradual restoration of natural fertility, increasing crop yields and animal productivity through biological methods of exposure, improving product quality, introducing and adapting energy and resource-saving technologies.

\section{Conclusions}

The transfer of agricultural production to the principles of more environmentally friendly production can be an impetus for the development of domestic agribusiness, which allows solving urgent tasks to reduce the environmental burden from agricultural production, restore land fertility, and develop export of domestic high-quality products, including organic ones. At the same time, the dynamic development of domestic biotechnological production and the emergence of competitive products can reduce import dependence on this category of goods 


\section{References}

1. Green Industrial Policy: Concept, Policies, Country Experiences UNEP (2011), available at www.unep.org/greeneconomy.

2. G. M. W. Lengai, J. W. Muthomi, E. R. Mbega Phytochemical activity and role of botanical pesticides in pest management for sustainable agricultural crop production Scientific African vol. 703 (2020), e00239 https://doi.org/10.1016/j.sciaf.2019.e00239.

3. Sustainable Development Goals, available at http://www.fao.org/sustainabledevelopment-goals/en/.

4. D. Kleijn, R. Bommarco, T. P. M. Fijen, L. A. Garibaldi, S. G. Potts, W. H. van der Putten Ecological Intensification: Bridging the Gap between Science and Practice Trends in ecology \& evolution vol. 34 Issue 202 154-166 (2019) https://doi.org/10.1016/j.tree.2018.11.002.

5. A.I. Petenko, A.N. Gneush, V.I. Dmitriev Improving the efficiency of obtaining a biological product based on the optimization of certain cultivation conditions for Pseudomonas sp114 Kuban State Agrarian University Polytopical Network Electronic Scientific Journal (KubGAU Scientific Journal) (Krasnodar: KubGAU) 06 (100), IDA: 1001406053 (2014), available at: http://ej.kubagro.ru/2014/06/pdf/53.pdf.

6. BIO-SILICIUM: innovation in agriculture, available at: http://old.agrovesti.ru/rubrika/article/bio-silicium-innovatsiya-vselskom-kh (accessed on $08 / 22 / 2019$ ).

7. V. Sharma, A. Sharma, R. Salwan Chapter 1-Overview and challenges in the implementation of plant beneficial microbes Molecular Aspects of Plant Beneficial Microbes in Agriculture 1-18 (2020) https://doi.org/10.1016/B978-0-12-8184691.00001-8.

8. V. S. Meena, S. K. Meena, J. P. Verma, A. Kumar, A. Aeron, P. K. Mishra, J. K. Bisht, A. Pattanayak, M. Naveed, M. L. Dotaniya Plant beneficial rhizospheric microorganism (PBRM) strategies to improve nutrients use efficiency Ecological Engineering vol. 107 10, 8-32 (2017) https://doi.org/10.1016/j.ecoleng.2017.06.058.

9. T.E. Marinchenko, V.N. Kuzmin, A.P. Korolkova, A.V. Goryacheva Monitoring of innovative activity in the field of agriculture Scientific and Analytical Overview (Moscow: Rosinformagrotekh) 104 (2018).

10. Safe plant growth regulator, available at: http://agrovesti.ru/rubrika/article/bezopasnyyregulyator-rosta-rasteniy (accessed on 09/22/2018).

11. K.V. Moiseeva, L.A. Safonova Efficiency of pre-sowing disinfection of spring wheat seeds Agro-food policy of Russia, 9 (69) 56-59 (2017)

12. New opportunities for plant nutrition, available at: URL:http://agrovesti.ru/rubrika/article/novye-vozmojnosti-.

13. A.P. Korolkova, V.N. Kuzmin, T.E. Marinchenko, A.V. Goryacheva Support and stimulation of demand for innovative products and technologies in the agricultural sector Scientific and Analytical Overview (Moscow: Rosinformigrotekh) 232 (2019).

14. A.P. Korolkova, V.N. Kuzmin, T.E. Marinchenko, A.V. Goryacheva Support and stimulation of demand for innovative products and technologies in the agricultural sector Silver Innovations for Crop Production, available at: http://agrovesti.ru/rubrika2018).]./article/agrovystavki-novinki-innovatsii (accessed on 09/06/2019).

15. M. Mącik, A. Gryta, M. Frąc Biofertilizers in agriculture: An overview on concepts, strategies and effects on soil microorganisms Advances in Agronomy, available at: https://doi.org/10.1016/bs.agron.2020.02.001 (accessed on 04/02/2020).

16. J. Gaffney, J. Bing, P. F. Byrne, K. G. Cassman, I. Ciampitti, D. Delmer, J. Habben, H. R. Lafitte, U. E. Lidstrom, D. O. Porter, J. E. Sawyer, J. Schussler, T. Setter, R. E. Sharp, 
T. J. Vyn, D. Warner Science-based intensive agriculture: Sustainability, food security, and the role of technology Global Food Security vol 2312 236-244 (2019), available at: https://doi.org/10.1016/j.gfs.2019.08.003Get rights and content. 